\title{
Monetary Architecture and the Green Transition
}

\author{
Steffen Murau $^{* \ddagger}$, Armin Haas ${ }^{\ddagger \S}$, and Andrei Guter-Sandu ${ }^{\dagger \otimes \oplus}$
}

How to finance the Green Transition towards net-zero carbon emissions remains an open question. The literature either operates within a market-failure paradigm that calls for a Pigou tax to help markets correct themselves, or via war finance analogies that offer a 'triad' of state intervention possibilities: taxation, treasury borrowing, and central bank money creation. These frameworks often lack a thorough conceptualisation of endogenous credit money creation, for instance when resorting to loanable funds theory, and disregard the systemic and procedural dimensions of financing the Green Transition. We propose that 'monetary architecture', which perceives the monetary and financial system as a constantly evolving and historically specific hierarchical web of interlocking balance sheets, offers a more comprehensive framework to conceptualize the systemic and procedural financing challenges. Using the US as an example, we draw implications of a systemic financing view while considering a division of labor between 'firefighting' institutions such as the Federal Reserve and the Treasury, and 'workhorse' institutions such as off-balancesheet fiscal agencies, commercial banks, and shadow banks. We argue further that financing the Green Transition must undergo three ideal-typical phases-initial balance sheet expansion, longterm funding, and possibly final contraction - that require diligent macro-financial management to avoid financial instability.

Keywords: Critical macro-finance; balance sheet; Federal Reserve; Treasury; shadow banking; off-balance-sheet fiscal agency; credit money; endogenous money; systemic financing; financial cycle; financial instability; financial crisis; carbon bubble; transition risk

\footnotetext{
${ }^{*}$ Boston University, Global Development Policy Center (GDPC)

${ }^{+}$City, University of London, City Political Economy Research Centre (CITYPERC)

${ }^{\ddagger}$ Global Climate Forum (GCF), Berlin

${ }^{\S}$ Institute for Advanced Sustainability Studies (IASS), Potsdam

${ }^{\otimes}$ University of Bath, Department of Politics, Languages \& International Studies

${ }^{\oplus}$ London School of Economics and Political Science, Centre for Analysis of Risk and Regulation (CARR)
} 


\section{Introduction}

The Green Transition - an economic and industrial reprogramming to net-zero carbon emissionsmore and more dominates discussions in the public sphere. Governments throughout the world are increasingly run by politicians with mandates to rebuild pandemic-stricken economies in a climateconscious fashion and to construct policies compatible with the Paris Agreement to which most have signed up. The challenge is immense, and the costs are proportionate to it. The price tag for a global transition to net-zero may amount to as much as $\$ 73$ trillion (Jacobson et al. 2019), although costs of $\$ 30$ to $\$ 60$ trillion have been suggested for the US only (Energy Transitions Commission 2020). Either way, a large part of the capital stock will have to be renewed within a generation-for instance in the fields of housing, transportation, infrastructure, agriculture, industry, and energy. This will entail mobilizing vast amounts of finance, usually seen only during periods of massive societal transformations.

Ever since Nicholas Stern's landmark report described climate change as 'the greatest market failure the world has ever seen' (Stern 2006), the dominant framework has been to see carbon emissions as an externality - a form of market failure - that is not adequately priced in an otherwise efficient economic system (Liu, Bauman, and Chuang 2019). The policy prescriptions stemming from this framework focus on market-correcting strategies that would 'internalize' this externality (Chenet, Ryan-Collins, and van Lerven 2021) — most prominently via carbon taxes or cap-and-trade. This is the world of Marshall and Pigou where the goal itself is not necessarily netzero but an optimal level of pollution that is determined through marginal analysis of benefits and costs of emissions and then achieved through the invisible hand of the (financial) market. There is broad agreement that some level of carbon pricing would be useful for accelerating the Green Transition (Stiglitz 2019; Stiglitz et al. 2017). However, warnings have also been issued that carbon pricing will not to trigger sufficient private sector investments to bring about the Green Transition (Lilliestam, Patt, and Bersalli 2021; Campiglio 2016), and that the political road to achieving a meaningful level at global scale is arduous if not inexistent, with carbon pricing initiatives so far stuck at covering only about a fifth of global greenhouse gas emissions (World Bank 2021). 
Beyond the market failure paradigm, another strand of literature addresses what the role of states may be in financing the Green Transition and often draws on war finance analogies (Monbiot 2021; Malm 2020) to sketch out a 'triad' of ways to achieve it: taxation, treasury borrowing, and central bank money creation. Taxation, in this case, rather than being market-correcting, involves the ramping up of any form of taxes to increase fiscal capacity (Boujou et al. 2019; Galbraith 2019). Next to paying for green state expenditure via general borrowing, the idea has been floated to issue specifically green sovereign bonds earmarked for projects with environmental benefits (Heine et al. 2019; Volz 2017; Monasterolo and Raberto 2018; Semmler et al. 2021). Central bank money creation has similarly been proposed, e.g. by advocates of Modern Monetary Theory (MMT) (Wray and Nersisyan 2019), Green Quantitative Easing (De Grauwe 2019; Pettifor 2019; Dafermos, Nikolaidi, and Galanis 2018), or Green Targeted Long-Term Refinancing Operations (van 't Klooster and van Tilburg 2020). As Dikau and Volz (2021) argue, the majority of central banks would have a respective mandate.

Compared to the market-failure paradigm, the 'triad' model has the advantage of acknowledging that financing the Green Transition might not happen simply by fixing market failures and that political impetus may well be crucial. However, from a macro-financial perspective (Gabor 2020), the triad framework has three shortcomings. First, taxation and treasury borrowing typically describe how a government can increase its cash flow which can then be used for investment through government expenditure. But this often follows the problematic conceptualisation of the loanable funds theory, which assumes that there is a defined quantity of ex ante financial resources that must be reallocated. While there is some merit to this view in commodity money systems, the opposite is true in a credit money system: New credit money is created ex nihilo when a financial institution gives a loan or purchases a bond from a counterparty. This implies that the monetary system has an inherent potential for expansion which can be leveraged for financing a large-scale transformation. While some reallocation of existing money, although insufficient, can potentially be beneficial, the bulk of money required for financing the Green Transition can be endogenously created, it does not have to be redistributed (Murau and Pforr 2020).

Second, the triad approach often lacks a systemic understanding. The volume of credit money needed for a large-scale transformation is so substantial that it cannot be borne solely by public institutions 
such as the central bank or the treasury; to assume that this can be done without far-reaching reverberations in the non-public sector is problematic. Rather, the entire or for the least a great part of the monetary and financial system must be harnessed systematically. The creation of credit money can be carried out both by public and private balance sheets such as commercial banks and shadow banks and in different parts of the system. Some recent scholarship hints at this (Chenet, RyanCollins, and van Lerven 2021; Hockett 2020) but as yet there is no fully developed framework.

Third, the triad approach ignores the procedural dimension. Financing a large-scale transformation is a long-term process that requires macro-financial management and coordination of different parts of the credit money system. Not only does the system have to deliver on a 'green initial expansion' to create credit money today, but it also has to fund it over a long period of time, avoid an implosion of the credit network, and eventually manage repayments and contraction later. Accounts that rightly emphasize the system's unlimited capacity to create credit money ex nihilo but disregard its subsequent progression through and impact on the system miss the complex procedural dynamics at play. This is important because there is nothing inherently less risky about an expansion in green assets (Dunz, Naqvi, and Monasterolo 2021; Cahen-Fourot et al. 2021; D'Orazio and Popoyan 2019) - these have to be processed and managed over the long term in a similar way to conventional assets.

To address these shortcomings, we propose to reframe the thinking around financing the Green Transition and mobilize the concept of 'monetary architecture' (Murau 2020) as a constantly evolving and hierarchical web of interlocking balance sheets that allows us to take endogenous credit money creation seriously and think about the systemic and procedural financing dimensions. Choosing the US as a case study, our framing of the monetary architecture comprizes central banks, treasuries, offbalance-sheet fiscal agencies (OBFAs), banks, and non-bank financial institutions (NBFIs), next to households, firms, and institutional cash pools. Each of these entities can be understood as a balance sheet with a particular financial position: there are other entities whom it owes obligations, i.e., 'liabilities', and others still who owe it obligations in turn, i.e., 'assets' (Minsky 1957; Mehrling 2013; Pozsar 2014). Drawing on this framework, we argue that meeting the systemic financing challenge of the Green Transition requires mobilizing and coordinating the entire monetary architecture, as well as 
acknowledging a division of labor between different types of balance sheets. Procedurally, it is necessary not only to have a strategy for how the monetary architecture can enable a green initial balance sheet expansion but also how the expansion can be funded over a long-term horizon without leading to a disorderly contraction and endangering the financial stability of the monetary architecture.

The remainder of this article develops our argument. Section 2 explains the monetary architecture framework envisaged to address issues on financing the Green Transition. Section 3 highlights the systemic financing dimension and considers a division of labor between different parts of the architecture. Section 4 argues via a three-phase scheme of the financial cycle that the procedural financing dimension entails currently neglected questions on funding and contraction. Section 5 concludes.

\section{Monetary architecture as a Conceptual Framework}

Our first argument is that 'monetary architecture' (Murau 2020) offers a useful conceptual lens to appropriately grasp the macro-financial challenges connected to financing the Green Transition. Monetary architecture is a shorthand to describe an institutionalist model of historically specific formations of the monetary and financial system as a web of interlocking balance sheets (Mehrling 2011) that is subject to continuous institutional evolution. Figure 1 presents an idealized model of the current US monetary architecture, which we use as an example and reference point. It is within this institutional setting that the financing of the Green Transition must occur.

The monetary architecture model represents on a higher level of abstraction how we see the present institutional setup in the US monetary jurisdiction, understood as a legal space (Awrey 2017). We look here at the US in isolation, abstracting from cross-border linkages to other monetary jurisdictions. By definition, a monetary architecture consists of four segments: central banks, commercial banks, NBFIs, as well as a fiscal ecosystem, which is made up of treasuries and OBFAs (Guter-Sandu and Murau 2021). In addition, we add firms, households, and institutional cash pools such as pension funds to the picture (Pozsar 2015). The institutions in these segments are represented as balance sheets. These can be either individual balance sheets as in the case of the Fed or the Treasury, or aggregate balance sheets

for households, firms, banks, etc. These institutions are either public (such as the Treasury), private (such as banks and NBFIs), or a hybrid of both (such as the Federal Reserve and OBFAs). 
Figure 1-The US monetary architecture as a web of interlocking balance sheets
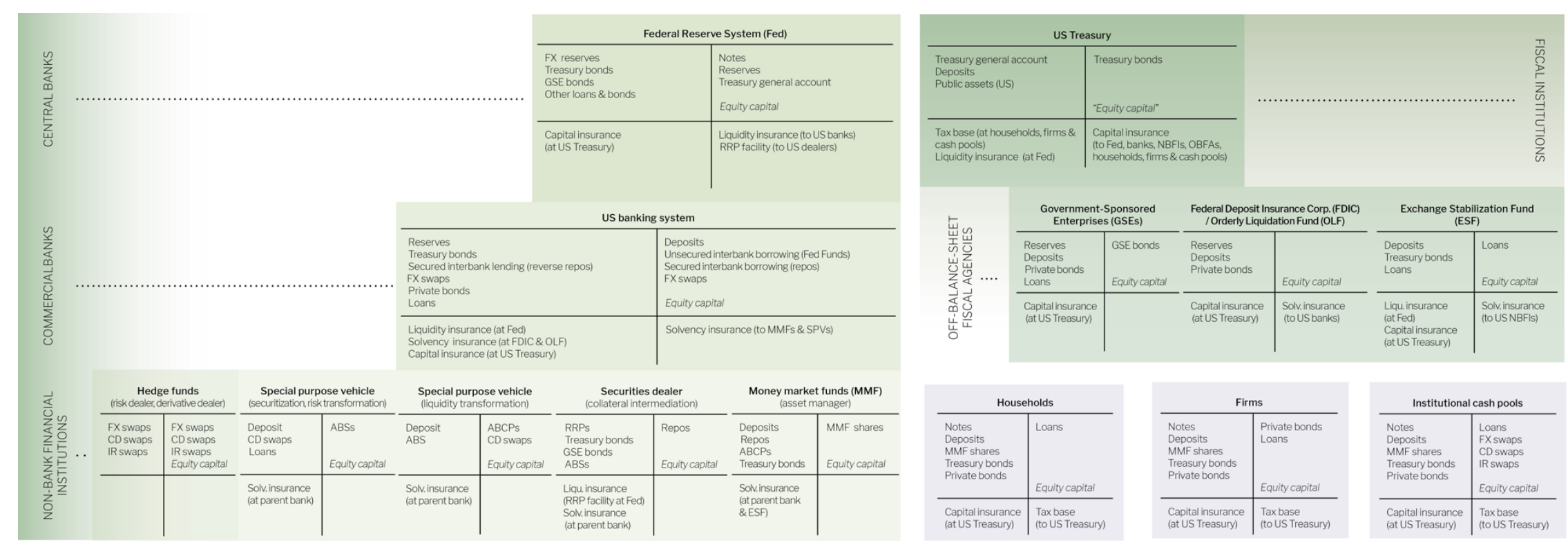

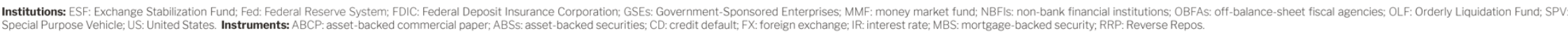


All these institutions interlock through the instruments they hold as assets (denoted on the lefthand side of each balance sheet) and liabilities (on the right-hand side). Each institution holds different credit instruments such as deposits, loans, or bonds as assets or liabilities on-balancesheet. Each asset of an institution must be another institution's liability. Due to this feature, the monetary architecture depicts a fully self-referential credit network. The setup of instruments on the balance sheet presented in the model should not be seen as the actual officially reported balance sheets of the institutions but as representations on a higher level of abstraction. Depicting an actual empirical web of interlocking balance sheets is an almost impossible task. Real balance sheets are not only data intense and permanently fluctuating, but also subject to changing accounting conventions and often based on ad hoc decisions that do not account for all promises to pay onbalance-sheet. Although treating all the institutions as in principle identical balance sheets is a simplification, it allows us to uncover their structural similarities within the system.

Some of the institutions have a hierarchical relationship with each other. For instance, central banks are hierarchically higher than commercial banks, which in turn are hierarchically higher than NBFIs. The hierarchical structure is due to the nature of payment systems which need central nodes through which payment flows are organized. This is true for banking systems, which typically have a central bank at the apex, and commercial banks and NBFIs that occupy layers below. We can expand this idea of hierarchy also to other balance sheets, integrating treasuries and OBFAs.

For each institution, we distinguish between actual and contingent assets and liabilities. The upper part of each balance sheet denotes the actual instruments, the lower part the contingent ones. Actual instruments are what you typically expect to find on a balance sheet. They can be measured and reported at a given moment in time. Assets are instruments that promise a future cash inflow, liabilities are commitments for a future cash outflow. Assets can be purely financial or physical, but we follow here the Minskyan idea that a house is also just a form of a bond that leads to future cash inflows and consequently treat it also as a financial asset (Minsky 1986). The residual between actual assets and actual liabilities is the institution's equity capital. By contrast, contingent assets and liabilities are 'counter-factual' instruments. Typically, they emerge only in a crisis - defined as the endogenous contraction of the credit money system - to compensate for the loss of assets on a given balance sheet. 
This implies that in such a crisis, the contingent assets and liabilities become actual assets and liabilities. As to Haldane and Alessandri (2009), contingent instruments can take the shape of-implicit or explicit-liquidity, solvency, or capital 'insurance' (they may also be called 'guarantees' or 'backstops') from higher-ranking to lower-ranking balance sheets. We depict them as contingent liabilities of the insuring institution and contingent assets of the insured institutions. Liquidity insurance is defined as the guarantee of the central bank to replenish another institution's holding of central bank money in a moment of scarcity. Solvency insurance is a mechanism to guarantee the nominal value of an institution's liabilities in case it defaults, which can be organized via funds or parent institutions. Capital insurance describes the treasury's de facto guarantee to 'recapitalize' or 'bail out' other balance sheets in case of negative equity capital. The counter-position is the treasury's ability to tax households, firms, and cash pools, which we can think of a contingent asset of the treasury.

What counts as money in the monetary architecture depends on a balance sheet's relative position in the hierarchy (Mehrling 2012). The system is organized around the transfer of public, private, and hybrid credit instruments ('IOUs', as in I owe you) that are issued as liabilities of higherranking institutions to function as monetary assets for lower-ranking institutions. First, money forms of the central bank involve notes issued for everyone, reserves for banks, and the treasury general account for the treasury. Second, commercial bank money is defined as deposits that are formally constructed as promises to pay central bank money, but no such central bank money is needed to create them. Deposits can be used by households, firms, and cash pools, treasuries and OBFAs, as well as different NBFIs. Third, NBFIs issue instruments which in some respects function as substitutes for deposits and may be called 'shadow money'. In our example, those are money market fund (MMF) shares, repurchase agreements (repos), and asset-backed commercial papers (ABCPs). They can be held by households, firms, cash pools, or other NBFIs (Murau 2017). The defining feature of the different types of money is that they have a stable price vis-à-vis each other-i.e. they trade at 'par', a one-to-one exchange rate.

The creation of credit money follows the logic of a 'swap of IOUs' between a hierarchically higher and a hierarchically lower institution. Since the model describes a fully self-referential system in which no 'outside' money such as gold exists (Gurley and Shaw 1960), money creation is fully 
endogenous to this system (Murau and Pforr 2020). In this context, central bank money can be construed as 'public inside money' which has also a credit character and which is created in a structurally parallel way as private bank money (Mehrling 2020). The only difference is that the central bank as the hierarchically highest money-issuing institution is relaxed of the immediate 'survival constraint' (Minsky 1957) - i.e. the danger of becoming illiquid in case it cannot meet its payment commitments - because its money forms are promises to pay nothing else but themselves.

Finally, each institution has a specific elasticity space. Any balance sheet can be extended to some degree by creating new credit instruments, which requires the simultaneous expansion of both assets and liabilities while interacting with another balance sheet as counterparty. The elasticity space describes the extent to which such an expansion on an individual balance sheet is possible and hence to which extent it is able to contribute to credit money creation and the provision of new financing.

We define a balance sheet's elasticity space as determined by three factors. The first factor is the willingness and ability of other institutions in the architecture to act as counterparty for balance sheet expansion and maintaining that level of expansion. This factor varies with the financial cycle. The elasticity space is wider in expansionary phases as it is easier for any balance sheet to find a counterparty. In contractionary phases, the elasticity space is lower. The second factor is the access that a balance sheet has to contingent instruments, i.e. mainly the extent to which hierarchically higher institutions - notably the central bank and the treasury — stand ready to supply them with emergency funds in a crisis. The third factor are the 'stipulations' for the allowed on-balance-sheet activities and how these stipulations are enforced. Stipulations is a broad term deliberately chosen to describe such restrictions because they manifest themselves differently in each of the four segments. For instance, commercial banks are subject to banking regulations which comprize rules such as reserve ratios or capital buffers and are enforced via supervision, whilst NBFIs face much milder forms of regulation and supervision. Central banks' on-balance-sheet activities are, if at all, 'regulated' through stipulations connected to their mandate, their level of institutional independence, and the collateral framework which determines the assets they are allowed to purchase. The US Treasury is constrained by the checks and balances of Congress's budget authority and the debt ceiling established with the Public Debt Acts of 1939 and 1941. 
The US monetary architecture as depicted in this model has not been consciously planned. Rather, it is the result of a historical process of institutional evolution and adaptation that is ongoing. For instance, the endowment of the US Treasury with the autonomous power to issue bonds (we imply here also other Treasury debt certificates such as bills) and the ability to function as general capital backstop (due to its power of taxation) cannot be taken as given naturally. In fact, the introduction of the federal US Treasury was highly controversial. It goes back to the 'assumption' initiated by Alexander Hamilton and was passed into law by Congress in 1790 (Frieden 2016). The Treasury's counterpart, the Fed, was only founded in 1913. For most of the 19th century, the US had a banking system without a central bank that would act as lender of last resort. There were some note issuing public banks, the First and Second Bank of the US, just as the Treasury issued notes-so-called Greenbacks - in the Civil War era. The reliance of the banking system on Treasury bonds as assets is a relic of the two World Wars and extensive Treasury-Fed collaboration that helped finance these wars. Due to the US's traditional reliance on long-term, rather than short-term debt, dealer banks have come to play a crucial role. The 1933 Glass-Steagall Act — a response to the Great Depressionseparated commercial banks from investment banks (here found under the label NBFIs, split up according to their main functions) and shaped the structure of the US monetary system, even though it was repealed in the 1990s (Mehrling 2011).

A central conceptual question is the relationship between the Fed and the Treasury, which are sometimes consolidated into a single government balance sheet (Kelton 2020). We do not adopt this perspective and treat them as independent institutions that are, however, mutually supportive. Upon its foundation, the Fed was intended to be an autonomous entity, designed following the Bank of England's model, that was supposed to be discounting firms' short-term commercial debt, but due to two world wars and massively extended sovereign debt issuance ended up supporting the Treasury bond market. The Treasury-Federal Reserve Accord of 1951 reestablished the Fed's policy autonomy (Conti-Brown 2016) and introduced what we see as reciprocal liquidity and solvency guarantees of Fed and Treasury. The degree of fiscal-monetary cooperation changes over time and arguably with the financial cycle. It has intensified after the 2007-9 Global Financial Crisis (GFC), for instance via the QE programs, in which the Fed purchases Treasury securities and the interventions in the Treasury market of March 2020 when the Covid-19 pandemic led to financial turmoil. 
At the same time, the Treasury is not a unitary actor but has several sub-balance sheets in the form of OBFAs to which it has relegated various functions while providing capital insurance (Guter-Sandu and Murau 2021). The US OBFAs are largely the result of the 1930s and New Deal Reforms. The Federal Deposits Insurance Corporation (FDIC) was introduced in 1933 to provide solvency insurance to the commercial banking system (Federal Deposit Insurance Corporation 1984). The Dodd-FrankAct extended this system with the Orderly Liquidation Fund (OLF). The Exchange Stabilization Fund (ESF) was introduced in 1934 to stabilize the international monetary system (Schwartz 1997) but has since then been used as a multipurpose vehicle, for instance to backstop the crumbling MMF industry in the GFC (Murau 2017). The oldest among the Government-sponsored Enterprises (GSEs), Fannie Mae, was founded in 1938 to expand the secondary mortgage market. The intention was to turn otherwise illiquid mortgages into tradable mortgage-backed securities (MBS), which was supposed to help address the housing crisis at the time. The sister institutions Ginnie Mae and Freddie Mac were founded in 1968 and 1970, respectively (Quinn 2019). The Reconstruction Finance Corporation (RFC), which was a key OBFA to organize large-scale investment after the Great Depression and in World War II, is not in the picture because it was dissolved in 1957 (Olson 2017).

From the 1970s onwards, the New Deal regulations led to a proliferation of new types of NBFIs and the emergence of what today is called the shadow banking or market-based credit system. NBFIs form a 'daisy chain' of balance sheets that jointly carry out a similar form of maturity, liquidity, and risk transformation as traditional commercial banks do on their own balance sheet (Pozsar et al. 2012). During this, they create shadow money. MMFs competed with commercial banks by offering depositlike accounts with higher interest rates, which was possible because they are not regulated as banks. ABPCs were issued on the balance sheets of Special Purpose Vehicles (SPVs), which commercial banks sponsored and endowed with solvency guarantees without having to expand their balance sheet and keeping more equity. The emergence of the tri-party repo market led to a new form of wholesale money market, competing with the Fed Funds market, which used short-term loans collateralized with US Treasury bonds and, prior to the GFC, with securitized private debt, first and foremost MBS issued by the GSEs (Murau 2017). While the shadow banking structures have been transforming over time, the Dodd-Frank-Act has barely touched them and they continue to be a prolific feature of the US monetary architecture. 


\section{Financing the Green Transition as a Systemic Challenge}

Our second argument is that financing the Green Transition as a politically desired large-scale transformation of capital stock requires a vast balance sheet expansion which can only be achieved when as much elasticity space of the real-world monetary architecture as possible is consciously mobilized. It is neither realistic to expect that 'the market' in the form of private banks and firms will make the right and sufficiently large investment decisions if only a well-made Pigou tax is in place, nor can individual public balance sheets such as the treasury, the central bank, or public investment banks alone raise and allocate the volume of capital required for the Green Transition.

To finance the Green Transition, some types of balance sheets in the monetary architecture must act as counterparties and expand, thereby issuing a short-term IOU that can be used as money to make investment into new capital stock as well as a longer-term IOU such as a loan or bond which promises payment of money in the future and can be held or traded on within the monetary architecture. The big question for financing the Green Transition is which institutions - or rather: which combination of institutions - should do this 'heavy lifting'? Whose elasticity space should be tapped into, and which instruments should be used?

The obvious expectation from an endogenous money perspective would be that the heavy lifting is done by banks and firms which act as counterparties (Minsky 1986; Moore 1988). Banks create credit money in the form of deposits and provide it to firms which in turn issue loans or bonds as their liabilities that banks can hold as assets. This is typically considered the main mechanism of money creation and financing investments in real capital stock in modern market economies. This financing technique, however, assumes that banks expect the investment to be both profitable and at an acceptable risk. However, investments that qualify for the Green Transition may often not have such a 'positive investment case' (cf. e.g. McKinsey \& Company 2020) as they require internalizing external effects, which by definition reduces their profitability. Therefore, we find that this technique is only rarely explicitly mentioned in the literature on financing the Green Transition, for instance by Campiglio (2016), although he also does not seem to believe that the entire heavy lifting for the Green Transition could be done this way. 
Instead, what we discover in much of the literature of both the market-failure and the triad paradigm is recourse to the loanable funds theory - a framework within which the question about the heavy lifting has little merit because balance sheets are not assumed to expand endogenously to provide financing. Rather, it is assumed that there is a limited, exogenously given volume of money-the 'loanable funds' - that must be distributed among different balance sheets in the monetary architecture to be spent on capital stock and hence finance real investments. From this angle, the Green Transition is imagined to be paid for exclusively by re-allocation of existing money stock, not by the creation of actually new credit money, and public balance sheets run the danger of crowding out private investment (Lamperti et al. 2019). Some of the market-failure paradigm literature uses the loanable funds theory explicitly (Carattini, Heutel, and Melkadze 2021), others seem to refer to it more implicitly when focusing on state investment banks or multilateral development banks, whichdespite their name - are no banks proper as they cannot create money (Skovgaard 2017). Likewise, some of the triad literature thinks about the Green Transition within the loanable funds framework. For instance, taxation implies that the treasury draws on the tax base as its contingent asset and extracts deposits from households and firms to then invest it, or treasury borrowing may be taken to imply that the treasury collects pre-existing money from households or firms with a promise to repay it later in the future.

Another part of the triad literature, in turn, does assume that the new money is being created when public balance sheets seek to raise money to finance the Green Transition. Treasury borrowing may be taken to entail the issuance of treasury bonds, facilitated by primary dealers who distribute them on to different secondary market participants, which could be banks that finance the purchase of bonds by expanding their balance sheet and create deposits, or the Fed, which could accept the bonds as assets and create new money on the Treasury General Account. The latter operation would be identical with what in the triad framework could be referred to as central bank money creation, a swap of IOUs between the central bank and the treasury. In addition, other ways are imagined how the central bank could provide the financing for green investments into capital stock. For instance, some Green QE proposals envision a direct interaction between the central bank and households or firms, which would receive central bank money in order to invest in capital stock (Pettifor 2019). 
Such operations could be imagined but are not presently common in the US monetary architecture (Omarova 2021).

These different ways of reflecting on how the heavy lifting could be carried out have in common that they only consider some selected institutions and their instruments and elasticity space in the monetary architecture. There is no 'systemic' view that would take into account all different types of balance sheets that presently exist. However, if the quoted numbers for financing the Green Transition are anything to go by, then the goal must be to mobilize as much elasticity space as possible. This may involve some re-distribution of funds and the usage of traditional ways for money creation but could also entail crowding in other institutions to use their instruments and elasticity space, or potentially setting up new ones. This is a pragmatic hybridity view which seeks to unveil more financing options and presents a systemic and holistic approach to the financing challenge of the Green Transition. We want to make three points of what this could entail.

First, the triad literature typically calls for a greater involvement of the central bank and the treasury, pointing to the massive transformations that the balance sheet of the Fed has undergone ever since the GFC, while the Covid-19 pandemic has only exacerbated this tendency with central banks launching historically unprecedented stimuli. With many other central banks increasingly shifting into climate issues (Dombret and Kenadjian 2021), the Fed faces increasing calls to integrate climate change considerations in its operation. There are two main approaches: The qualitative one focuses on changing the composition of central banks' balance sheets, the quantitative one on enlarging the balance sheet by adding green assets. The Fed has so far been resistant to both these options. Although it has recently joined the Network for Greening the Financial System (NGFS) and created two internal committees aimed at exploring this issue (Brainard 2021), Fed chairman Jerome Powell has repeatedly reinforced the message that climate change is not something the Fed directly considers in setting monetary policy, although it is exploring its role in the oversight of the financial system. The key question is whether these measures would actually strengthen central banks' abilities to safeguard their respective monetary jurisdictions, or put these abilities at risk. It is probably fair to say that researching this crucial question has not yet started in earnest. Moreover, it cannot be ruled out that the most important role for central banks concerning the Green Transition might be to keep the system stable long-term, and that they should therefore focus on exactly this. 
Reservations about the excessive use of central bank but also treasury balance sheets are often shrugged off as a stance of monetary and fiscal conservatives who do not share the same progressive cause. However, there are other reasons to caution against the excessive use of elasticity space at the top of the hierarchy to finance the Green Transition. From a systemic perspective, balance sheets in a monetary architecture exhibit a particular division of labor. The hierarchically highest balance sheets — as the structure of contingent assets and liabilities showsare the ultimate liquidity and capital insurers. We can think of them as the 'firefighters' who use their potentially unlimited elasticity space to intervene and safeguard the system. The exorbitant balance sheet expansion of the Fed during the GFC and of the Treasury during the Covid-19 pandemic reinforces this. These hierarchically highest balance sheets do not typically engage in credit allocation measures, not least because there is no more hierarchically higher balance sheet left to backstop them. Hence, the 'workhorses' in a monetary architecture are the hierarchically lower institutions. It is their elasticity space that should shoulder the lion share of the expansion.

Second, while commercial banks may be seen as the go-to institutions for financing investment in capital stock, the largest elasticity space in the US monetary architecture is to be found in the shadow banking system. The question is whether it could be beneficial to harness the elasticity space on the various NBFI balance sheets for financing the Green Transition and, if so, how and to which extent. The idea to mobilize shadow banking balance sheets for financing the Green Transition is contested, and maybe for a good reason. Not only were shadow banking structures the main culprits of the GFC, they also circumvented the New Deal era safety features for the banking system and have played a major role in enhancing wealth inequality (Caverzasi, Botta, and Capelli 2019; Helgadóttir 2016). The argument often heard prior to 2007 that shadow banking structures are efficiencyenhancing has largely disappeared. Still, rather than treating financing the Green Transition as one superproject geared at financial expansion and regulating the shadow banking system as another superproject seeking to achieve financial contraction, it may be beneficial to change the perspective and ask how these institutional structures can be productively integrated in the financing challenge of the Green Transition. Not only can the shadow banking sector be decarbonized by for instance calibrating the greenness of assets providing the collateral in repo agreements and securities lending (Dafermos et al. 2021), but it may also be that some routine shadow banking practices like 
securitization - a tainted but still integral practice to the financial sector — can actively be leveraged by investment banks for buying up cash flows related to low-carbon assets from firms and banks in order to free up more capacity for them to invest in green activities.

Third, while many proposals in the triad literature focus on the Treasury as the quintessential public institution, a lesson from the New Deal era is that large-scale transitions of capital stock can be well financed through OBFAs. These could be existing ones or newly created ones. The latter might have more policy autonomy vis-à-vis the existing institutions. OBFAs do not have to function as ultimate capital backstop and, given that they are public-private hybrids, are subject to less stipulations limiting their elasticity space. Not only could they use their own elasticity space to finance green investment, they also are in the position to crowd in other balance sheets such as firms, cash pools, or NBFIs that are part of the shadow banking system. An existing proposal for a US OBFA solution to finance the Green Transition is to set up a Federal Investment Agency (Hockett and Omarova 2018), which could be useful to circumvent existing political constraints in the US Congress regarding the use of the US Treasury's elasticity space. OBFAs could mobilize their own balance sheet to provide additional elasticity space for the monetary architecture by issuing bonds earmarked for green projects, or they could steer the monetary architecture in the direction of financing the Green Transition by, for instance, providing equity capital in blended finance initiatives to de-risk investments or funding existing green bonds by bulk-buying and securitizing them. An alternative would be a green GSE which would engage in green securitization and would issue green agency bonds that, if it receives Fed backing, could also act as a novel safe asset.

It is worth taking the division of labor between firefighting and workhorse balance sheets seriously. Firefighting balance sheets can become politically contentious and constrained, and thus serve their objectives with less effectiveness, as demonstrated by recent concerns about inflation and increasing pressures to downsize the balance sheets of central banks by winding down asset purchases or to quell public spending and start repaying the pandemic-induced ballooning of public debt. In conjunction with firefighting balance sheets, workhorse balance sheets like shadow banking institutions and OBFAs should therefore also play an active part in financing the Green Transition. 


\section{Systemic Financing of the Green Transition as a Procedural Challenge}

Our third argument is that financing the Green Transition is a long-term process that requires diligent macro-financial governance and coordination of different parts of the monetary architecture. Not only do the balance sheets in the monetary architecture have to create credit money today, they also have to put it to productive use over a long period of time, avoid an implosion of the credit network, and find a solution for the inherent need to repay the debts later.

To substantiate our argument, we present a simple scheme in Figure 2 which suggests that systemically financing a large-scale transformation such as the Green Transition must comprize three ideal-typical phases of a financial cycle: initial expansion, long-term funding, and final contraction. This scheme takes on board ideas on the financial cycle of the Money View (Mehrling 2020) as well as monetary circuitistes and Post Keynesians (Bonizzi and Kaltenbrunner 2020).

Figure 2-Three phases of financing large-scale transformations

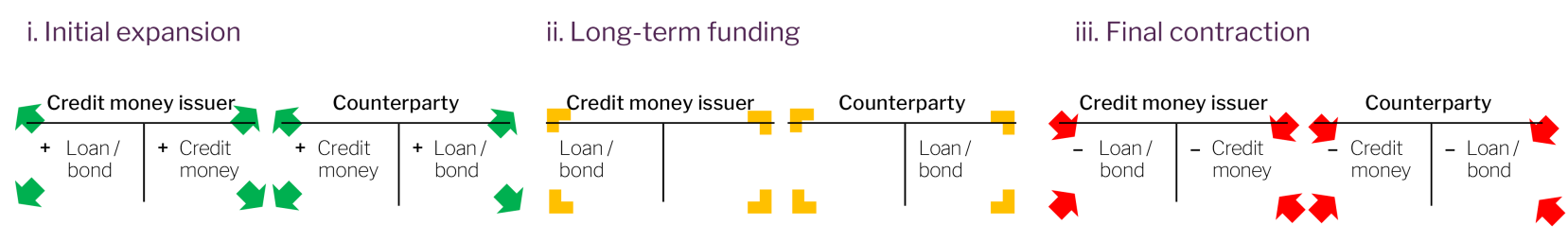

The scheme starts with an initial expansion of balance sheets within the monetary architecture during which financing is provided via a swap of IOUs between different types of balance sheets. Subsequently, the monetary architecture must 'fund' the investment over a long-term horizon. This means that the initial balance sheet expansion must be maintained in the system ceteris paribus while the actual instruments created change in between balance sheets. The short-term IOUs (credit money) have to be used for investments in physical capital stock while the long-term IOUs must be distributed to balance sheets that are willing and able to hold them over a long time horizon (Mehrling 2020). As different balance sheets are in charge of an initial expansion and long-term funding, the transition between both steps is a major challenge in the financing of a large-scale transformation. This involves making sure not only that the credit money created is used for the appropriate investment purposes but also that the long-term IOUs are not paid back too soon or 
have to be liquidated in a credit crunch. At the end of the financial cycle, when the funding phase is over and repayment is due, the final contraction should occur-ideally in an orderly fashion as outstanding loans and bonds are repaid, and the monetary architecture reverts to the initial level of expansion. Rochon (1999) refers to it as 'monetary reflux' that comes along with a 'destruction of money' as the monetary circuit comes to an end; Graziani (1989) calls it 'final finance'.

As the three phases are ideal types, they of course cannot be perfectly distinguished in practice. Nevertheless, this approach gives us a useful way of thinking about the procedural challenges of financing the Green Transition. In fact, the literature on financing the Green Transition almost exclusively focuses on the phase of a green initial expansion-and sometimes correctly notices that there is no objective limit to it (Wray and Nersisyan 2019; Kelton 2020) — but affords a much lesser importance to the funding and contraction phases. However, if the history of financing cycles and financial innovation is any indication, questions of funding and contraction are essential for determining if financing the Green Transition can succeed, while overlooking them may lead to deleterious consequences down the line.

First, let us address phase (ii), the issue of long-term funding a green initial expansion. Take the example of an energy company, which issues a $\$ 250 \mathrm{~m}$ green project bond with a maturity of eight years to fund an offshore wind project which it places with a consortium of a pension fund and two insurance groups. The proceeds from the bond go into the short-term development of the project, while the bond itself must be maintained or distributed to balance sheets willing and able to hold it over its life-course. This poses challenges because institutions must be able to constantly price the bond and not liquidate it in a fire sale, which ultimately depends on the capacity of the company to deliver on its agreed-upon project. This also requires a set of institutional substructures such as a standardized green accounting system, disclosure requirements, or even a green buyer of last resort, all of which contribute to creating a liquid secondary market that would constitute the infrastructure through which the IOU would exchange hands (Carruthers and Stinchcombe 1999). The basic question is whether this infrastructure for long-term funding is already in place or has to be created, and whether the confidence and expectations of players involved can be nurtured and managed. One limiting factor of establishing an infrastructure conducive to funding a green 
initial expansion is the lack of standards for what constitutes a legitimate 'green asset'. The US does not have an agreed taxonomy that would facilitate green investments, although US regulators are looking at the EU as a possible model for future regulation (Engler 2021). The EU is currently in the process of establishing a Green Taxonomy, which may entail making green reporting mandatory for companies in the future, with the establishment and tightening of binding targets as the final step. The European Banking Authority (2021) has already proposed key performance indicators for the disclosure by credit institutions and investment firms of information on how and to what extent their economic activities are environmentally sustainable in line with the Green Taxonomy. Furthermore, the European Commission has recently announced that EU banks will need to report their Green Asset Ratio, starting in 2024 (FitchRatings 2021). Another suggestion is to require banks to discriminate between green and non-green assets and to either decrease the equity ratio for green assets or to increase the equity ratio of non-green assets (Mack 2021).

Moreover, there is disagreement as to whether a green initial expansion, if carried out at a large scale, would lead to distortions of the price level that would undermine the feasibility of managing its longterm funding. At one end of the spectrum, there is the position - represented e.g. by MMT authorsthat there is no financial limit to expanding central bank and treasury balance sheets to create public money for financing the Green Transition. Limits, if they occur, originate in the real sector when specific factors of production become scarce. MMT authors do not fear inflation as treasuries can tax away any excess purchasing power that would fuel inflation (Nersisyan and Wray 2019; Kelton 2020). At the other end of the spectrum, there is the position held by proponents of more orthodox monetary and fiscal policies who worry particularly about the potential for runaway inflation (Dubay 2019; Edwards 2019; Summers 2019; Rogoff 2019).

Second, regarding the transition from phase (ii) to phase (iii), it is an open theoretical question if it is indeed the case that a green initial expansion ever has to be reverted with an orderly final contraction or if the monetary architecture should rather be permanently kept in the funding phase by continuously rolling over existing debts without clear intentions to repay them-a common practice in sovereign debt markets to-date. In general, there are no impediments to rolling over green sovereign bonds indefinitely as long as the counterparties in the monetary architecture agree on it and provided there are no stipulations for the balance sheets involved that would prevent it. 
Moreover, if the central bank either buys green assets outright or accepts them as eligible collateral, it can contribute substantially to entrenching them in the funding phase for the long term.

Empirically, this relates to the measurement and interpretation of what happens when historic financial cycles came to an end. Straightforward candidates are financial cycles related to big societal challenges such as the financing of large wars. Arguably, the financial expansion to finance the world wars led to two sovereign bankruptcies in Germany who lost them, whereas the US as the victor never ceased funding the initial balance sheet expansion but has in fact outgrown it. The composition of the Fed's balance sheet and the structure of the US Treasury market are direct consequences of this (Garbade 2012; Mehrling 2011).

Third, a particular challenge is if phase (iii) kicks in early, i.e. if a green initial expansion cannot be sustainably funded and ends in an unexpected disorderly contraction. Financial stability risks connected to climate change are currently debated as the possibility of physical 'Green Swan' events that create financial turmoil as an exogenous shock (Bolton et al. 2020), or as transition risks that emerge because the Green Transition creates stranded carbon-intensive assets which suddenly lose their market value and hence reduce the equity capital of those balance sheets in the monetary architecture who hold them (Chenet, Ryan-Collins, and van Lerven 2021; D'Orazio and Popoyan 2019). However, the bursting of a possible 'green financial bubble' created by a green initial expansion is not a well-established position in the green finance literature - this topic has only recently started to get some attention (Brav and Heaton 2021; Heger and Åkerman 2021).

After a green initial expansion, some green investments in risky projects will fail with necessity. Green investments can fail either on their returns or on their greenness, i.e. they may in fact turn out to be greenwashed and their value might plummet if there are green valuation mechanisms in place. If the failure of green investments is idiosyncratic, this will not entail a financial stability risk. The monetary architecture has developed balance sheets such as banks, NBFIs, or some cash pools that are specialized on hedging in risk and diversifying it in their investment portfolios. However, there are historical examples when these mechanisms have not worked as intended. For instance, the GFC followed a massive proliferation of asset-backed securities and the subsequent breakdown in the capacity of the monetary architecture to price them and thus maintain long-term funding (Milne 
2009). The expansion of GSE bonds such as mortgage-backed securities (MBS) was made possible by the activities of New Deal-era OBFAs, which started off as institutions meant to fulfil public policy objectives - in this case, widening homeownership by creating a secondary market for mortgages (Quinn 2019). However, it should be seen as a warning sign that a public policy facilitated the creation of the shadow banking system as an entire financial ecosystem which led to the spectacular breakdown in the GFC. Therefore, incentivizing the unfettered creation of green assets without heeding the procedural aspects of long-term funding and final contraction might have unintended consequences that not only put the financial system under peril but also the transition to a sustainable socio-economic system.

Therefore, it is important to think carefully about how a green initial expansion can be sustainable by finding ways to fund it over a long-time horizon and deal with the prospects of both an orderly and a disorderly contraction. This is not a matter of fetishising financial stability while the world's ecosystem collapses - both are certainly interconnected. However, it cannot be in anyone's interest when a green expansion collapses mid-way, just as it is in no one's interest to continue ignoring finance's role in funding environmental breakdown. If questions regarding systemic funding and contraction of a green initial expansion are kept as a black box, it is left to the infamous invisible hand of the (financial) market to decide whether the financing of the Green Transition succeeds. If carefully managed throughout the entire financing process, green assets can help us avoid major societal risks. If mismanaged, they can actually trigger major societal risks - just of another kind. It would be a tragedy if we were to trade one collapse for another. 


\section{Conclusion}

This article contributes to the literature on the Green Transition by mobilizing the monetary architecture framework to think about the financing challenge. The framework underlines how the monetary and financial system is a constantly evolving and hierarchical web of interlocking balance sheets. Using the US as a case study, we have stressed the importance of a systemic financing dimension that crowds in the available elasticity space in the monetary architecture while taking into account a division of labor between firefighting balance sheets such as central banks or treasuries and workhorse balance sheets such as the shadow banking sector or various OBFAs. This allows firefighting balance sheets to focus on system stability, while the shadow banking sector may be tapped into for its vast potential for balance sheet elasticity, at the same time as OBFAs may be used to take initiative in steering the monetary architecture towards green public policy objectives.

Moreover, we have pointed to the procedural financing dimension that considers not only the green initial expansion but also questions of long-term funding and contraction. We argue that for the Green Transition to be successful, we need to have mechanisms in place that enable continuous funding of green assets as well as a strategy for orderly contraction and the prevention of financial instability originating from a potential green bubble. As the monetary architecture is never static but subject to continuous institutional change, we should expect that the Green Transition will have a considerable impact on its setup-just as the New Deal has profoundly shaped how the US monetary architecture looks today.

Our analysis seeks to unveil financing options beyond those discussed in the market-failure and the triad paradigm that often rely on loanable funds theory, which is insufficiently able to grasp the financing process, or seek to use firefighting balance sheets for tasks that would better be carried out by workhorse balance sheets. Currently, there is a striking absence of analytical tools suitable for thinking of financing the Green Transition as a systemic and procedural challenge. By introducing the monetary architecture framework and exploring its systemic and procedural implications, we have attempted to provide the groundwork for meeting this challenge. And yet, there are still unanswered questions, not least how the phase of final contraction after a green initial expansion should or is likely to work out. We believe that these questions should be subject of future research. 


\section{References}

Awrey, Dan. 2017. "Brother, Can You Spare a Dollar? Designing an Effective Framework for Foreign Currency Liquidity Assistance.” Columbia Business Law Review 2017 (3): 9341016.

Bolton, Patrick, Morgan Despres, Luiz Awazu Pereira Da Silva, Frédéric Samama, and Romain Svartzman. 2020. "The Green Swan. Central Banking and Financial Stability in the Age of Climate Change.” Basel: Bank for International Settlements.

Bonizzi, Bruno, and Annina Kaltenbrunner. 2020. "Critical Macro-Finance, Post-Keynesian Monetary Theory and Emerging Economies." Finance and Society 6 (1).

Boujou, Manon, Lucas Chancel, Anne-Laure Delatte, Thomas Piketty, Guillaume Sacriste, Stéphanie Hennette, and Antoine Vauchez. 2019. "Democratising Europe. By Taxation or by Debt?" Social Europe. https://www.socialeurope.eu/democratising-europe.

Brainard, Lael. 2021. "Speech by Governor Brainard on Financial Stability Implications of Climate Change." Board of Governors of the Federal Reserve System. March 31, 2021. https://www.federalreserve.gov/newsevents/speech/brainard20210323a.htm.

Brav, Alon, and J. B. Heaton. 2021. "Brown Assets for the Prudent Investor."

Cahen-Fourot, Louison, Emanuele Cempiglio, Louis Daumas, Michael Gregor Miess, and Andrew Yardley. 2021. "Waiting for the Transition: The Role of Expectations in the Decarbonisation of the Electricity Sector."

Campiglio, Emanuele. 2016. "Beyond Carbon Pricing. The Role of Banking and Monetary Policy in Financing the Transition to a Low-Carbon Economy." Ecological Economics 121: $220-30$.

Carattini, Stefano, Garth Heutel, and Givi Melkadze. 2021. "Climate Policy, Financial Frictions, and Transition Risk." National Bureau of Economic Research.

Carruthers, Bruce G., and Arthur L. Stinchcombe. 1999. "The Social Structure of Liquidity: Flexibility, Markets, and States." Theory and Society 28 (3): 353-82.

Caverzasi, Eugenio, Alberto Botta, and Clara Capelli. 2019. "Shadow Banking and the Financial Side of Financialisation." Cambridge Journal of Economics 43: 1029-51.

Chenet, Hugues, Josh Ryan-Collins, and Frank van Lerven. 2021. "Finance, Climate-Change and Radical Uncertainty: Towards a Precautionary Approach to Financial Policy.” Ecological Economics 183: 106957.

Conti-Brown, Peter. 2016. The Power and Independence of the Federal Reserve. Princeton: Princeton University Press.

Dafermos, Yannis, Daniela Gabor, Maria Nikolaidi, and Frank van Lerven. 2021. "Greening the UK Financial System - a Fit for Purpose Approach.” 226. SUERF Policy Notes. London: The European Money and Finance Forum. https://www.suerf.org/policynotes/21233/greening-the-uk-financial-system-a-fit-forpurpose-approach.

Dafermos, Yannis, Maria Nikolaidi, and Giorgos Galanis. 2018. "Climate Change, Financial Stability and Monetary Policy." Ecological Economics 152: 219-34.

De Grauwe, Paul. 2019. “Green Money Without Inflation.” Vierteljahrshefte Zur Wirtschaftsforschung 88: 51-54.

Dikau, Simon, and Ulrich Volz. 2021. "Central Bank Mandates, Sustainability Objectives and the Promotion of Green Finance.” Ecological Economics 184 (June): 107022. https://doi.org/10.1016/j.ecolecon.2021.107022. 
Dombret, Andreas, and Patrick Kenadjian, eds. 2021. Green Banking and Green Central Banking. Green Banking and Green Central Banking. Berlin/Boston: De Gruyter. https://doi.org/10.1515/9783110752892.

D’Orazio, Paola, and Lilit Popoyan. 2019. "Fostering Green Investments and Tackling ClimateRelated Financial Risks: Which Role for Macroprudential Policies?” Ecological Economics 160 (June): 25-37. https://doi.org/10.1016/j.ecolecon.2019.01.029.

Dubay, Curtis. 2019. "Modern Monetary Theory, Inflation and the Banking Industry." ABA Banking Journal 111 (4): 56-56.

Dunz, Nepomuk, Asjad Naqvi, and Irene Monasterolo. 2021. "Climate Sentiments, Transition Risk, and Financial Stability in a Stock-Flow Consistent Model." Journal of Financial Stability 54: 100872.

Edwards, Sebastian. 2019. "Modern Monetary Theory: Cautionary Tales from Latin America." Cato Journal 39.

Energy Transitions Commission. 2020. "Making Mission Possible: Delivering a Net-Zero Economy.” Energy Transitions Commission. https://www.energytransitions.org/publications/making-mission-possible/.

Engler, Henry. 2021. "U.S. Regulators Seen Developing 'Green Taxonomy' to Provide Guidance to Financial Firms." Reuters. July 14, 2021. https://www.reuters.com/legal/transactional/us-regulators-seen-developing-greentaxonomy-provide-guidance-financial-firms-2021-07-14/.

European Banking Authority. 2021. "Opinion of the EBA on the Disclosure Requirement on Environmentally Sustainable Activities in Accordance with Article 8 of the Taxonomy Regulation.” EBA/Op/2021/03.

Federal Deposit Insurance Corporation. 1984. The First Fifty Years. A History of the FDIC 19331983. Washington D.C.: Federal Deposit Insurance Corporation.

FitchRatings. 2021. "Final Green Asset Ratio Rules to Improve EU Bank Comparability." https://www.fitchratings.com/research/banks/final-green-asset-ratio-rules-to-improve-eubank-comparability-09-07-2021.

Frieden, Jeffry. 2016. Lessons for the Euro from Early American Monetary and Financial History. Brussels: Bruegel Essay and Lecture Series.

Gabor, Daniela. 2020. "Critical Macro-Finance. A Theoretical Lens." Finance and Society 6 (1): $45-55$.

Galbraith, James K. 2019. "Financing the Green New Deal in Europe.” Social Europe. $\mathrm{https}$ ://www.socialeurope.eu/financing-the-green-new-deal.

Garbade, Kenneth D. 2012. Birth of a Market. The U.S. Treasury Securities Market from the Great War to the Great Depression. Cambridge (MA): MIT.

Gurley, John G., and Edward S. Shaw. 1960. Money in a Theory of Finance. Washington D.C.: Brookings Institution.

Guter-Sandu, Andrei, and Steffen Murau. 2021. "The Transformation of Eurozone Fiscal Governance. Mitigating Fiscal Discipline through a Proliferation of Off-Balance-Sheet Fiscal Agencies." New Political Economy https://doi.org/10.1080/13563467.2021.1910648.

Haldane, Andrew, and Piergiorgio Alessandri. 2009. "Banking on the State." Chicago: Bank of England.

Heger, Levin, and Lisa Åkerman. 2021. Momentum in ESG Indexes: A Study on the Passive Capital Flows Effect on ESG Stock Prices. 
Heine, Dirk, Willi Semmler, Mariana Mazzucato, Joao Paulo Braga, Arkady Gevorkyan, Erin Kate Hayde, and Siavash Radpour. 2019. "Financing Low-Carbon Transitions Through Carbon Pricing and Green Bonds." SSRN Scholarly Paper ID 3440367. Rochester, NY: Social Science Research Network. https://papers.ssrn.com/abstract=3440367.

Helgadóttir, Oddny. 2016. "Banking Upside down: The Implicit Politics of Shadow Banking Expertise." Review of International Political Economy 23 (6): 915-40.

Hockett, Robert C. 2020. Financing the Green New Deal. Palgrave Macmillan.

Hockett, Robert C., and Saule Omarova. 2018. "White Paper. A National Investment Authority." Legal Studies Research Paper Series No. 18-10. Ithaca: Cornell Law School.

Jacobson, Mark Z., Mark A. Delucchi, Mary A. Cameron, Stephen J. Coughlin, Catherine A. Hay, Indu Priya Manogaran, Yanbo Shu, and Anna-Katharina von Krauland. 2019. "Impacts of Green New Deal Energy Plans on Grid Stability, Costs, Jobs, Health, and Climate in 143 Countries." One Earth 1 (4): 449-63. https://doi.org/10.1016/j.oneear.2019.12.003.

Kelton, Stephanie. 2020. The Deficit Myth. Modern Monetary Theory and the Birth of the People's Economy. New York: Public Affairs.

Klooster, Jens van 't, and Rens van Tilburg. 2020. "Targeting a Sustainable Recovery with Green TLTROs.” PositiveMoney and Sustainable Finance Lab.

Lamperti, Francesco, Mariana Mazzucato, Andrea Roventini, and Gregor Semienuk. 2019. "The Green Transition: Public Policy, Finance, and the Role of the State." Vierteljahrshefte Zur Wirtschaftsforschung 88 (2): 73-88.

Lilliestam, Johan, Anthony Patt, and Germán Bersalli. 2021. "The Effect of Carbon Pricing on Technological Change for Full Energy Decarbonization: A Review of Empirical Ex-Post Evidence." WIREs Climate Change 12 (1): e681. https://doi.org/10.1002/wcc.681.

Liu, John Chung-En, Yoram Bauman, and Yating Chuang. 2019. "Climate Change and Economics 101: Teaching the Greatest Market Failure.” Sustainability 11 (5): 1340. https://doi.org/10.3390/su11051340.

Mack, Sebastian. 2021. "Beyond Transparency: Getting Serious about Greening Europe's Financial System."

Malm, Andreas. 2020. Corona, Climate, Chronic Emergency: War Communism in the TwentyFirst Century. Verso Books.

McKinsey \& Company. 2020. "Net-Zero Europe. Decarbonization Pathways and Socioeconomic Implications." Vienna et al.: McKinsey \& Company.

Mehrling, Perry. 2011. The New Lombard Street. How the Fed Became the Dealer of Last Resort. Princeton and Oxford: Princeton University Press. . 2012. "The Inherent Hierarchy of Money." In Social Fairness and Economics. Economic Essays in the Spirit of Duncan Foley, edited by Lance Taylor, Armon Rezai, and Thomas Michl, 394-404. Oxon and New York: Routledge.

- 2013. "Essential Hybridity: A Money View of FX." Journal of Comparative Economics, Law in Finance, 41 (2): 355-63. https://doi.org/10.1016/j.jce.2013.03.007. . 2020. "Payment vs. Funding. The Law of Reflux for Today." Working Paper No. 113. Boston: Institute for New Economic Thinking.

Milne, Alistair. 2009. The Fall of the House of Credit: What Went Wrong in Banking and What Can Be Done to Repair the Damage? Cambridge, UK ; New York: Cambridge University Press. 
Minsky, Hyman P. 1957. "Central Banking and Money Market Changes." The Quarterly Journal of Economics 71 (2): 171-87. https://doi.org/10.2307/1883812.

- 1986. Stabilizing an Unstable Economy. New Haven and London: Yale University Press.

Monasterolo, Irene, and Marco Raberto. 2018. "The EIRIN Flow-of-Funds Behavioural Model of Green Fiscal Policies and Green Sovereign Bonds." Ecological Economics 144: 22843.

Monbiot, George. 2021. "Think Big on Climate: The Transformation of Society in Months Has Been Done Before." The Guardian, October 20, 2021, sec. Opinion. https://www.theguardian.com/commentisfree/2021/oct/20/us-war-footing-1941-climateemergency-earth-pearl-harbor.

Moore, Basil J. 1988. Horizontalists and Verticalists. The Macroeconomics of Credit Money. Cambridge: Cambridge University Press.

Murau, Steffen. 2017. "Shadow Money and the Public Money Supply. The Impact of the 20072009 Financial Crisis on the Monetary System." Review of International Political Economy 24 (5): 802-38.

- 2020. "A Macro-Financial Model of the Eurozone Architecture Embedded in the Global Offshore US-Dollar System.” GEGI Study July 2020. Boston, MA: Global Development Policy Center, Global Economic Governance Initiative (GEGI), Boston University. https://doi.org/10.2312/iass.2020.041.

Murau, Steffen, and Tobias Pforr. 2020. "What Is Money in a Critical Macro-Finance Framework?" Finance and Society 6 (1): 56-66.

Nersisyan, Yeva, and Larry Randall Wray. 2019. "How to Pay for the Green New Deal." Working Paper.

Olson, James Stuart. 2017. Saving Capitalism. The Reconstruction Finance Corporation and the New Deal, 1933-1940. Princeton: Princeton Legace Library.

Omarova, Saule T. 2021. "The People's Ledger. How to Democratize Money and Finance the Economy." Vanderbilt Law Review 74 (5): 1231-1300.

Pettifor, Ann. 2019. The Case for the Green New Deal. London: Verso.

Pozsar, Zoltan. 2014. "Shadow Banking: The Money View." SSRN Scholarly Paper ID 2476415. Rochester, NY: Social Science Research Network. https://doi.org/10.2139/ssrn.2476415.

_ 2015. "A Macro View of Shadow Banking. Levered Betas and Wholesale Funding in the Context of Secular Stagnation." Working Paper. Institute for New Economic Thinking.

Pozsar, Zoltan, Tobias Adrian, Adam Ashcraft, and Hayley Boesky. 2012. "Shadow Banking." Staff Report 458. Federal Reserve Bank of New York.

Quinn, Sarah. 2019. American Bonds. How Credit Markets Shaped a Nation. Princeton and Oxford: Princeton University Press.

Rogoff, Kenneth. 2019. “Modern Monetary Nonsense.” Project Syndicate (blog). April 3, 2019.

Schwartz, Anna J. 1997. "From Obscurity to Notoriety. A Biography of the Exchange Stabilization Fund." Journal of Money, Credit and Banking 29 (2): 135-53.

Semmler, Willi, Joao Paulo Braga, Andreas Lichtenberger, Marieme Toure, and Erin Hayde. 2021. "Fiscal Policies for a Low-Carbon Economy." 
Skovgaard, Jakob. 2017. "Limiting Costs or Correcting Market Failures? Finance Ministries and Frame Alignment in UN Climate Finance Negotiations." International Environmental Agreements: Politics, Law and Economics 17 (1): 89-106.

Stern, Nicholas. 2006. “The Economics of Climate Change." London: HM Treasury. UK. https://webarchive.nationalarchives.gov.uk/ukgwa/20100407172811mp_http://www.hmtreasury.gov.uk/stern_review_report.htm.

Stiglitz, Joseph E. 2019. "Addressing Climate Change through Price and Non-Price Interventions." European Economic Review 119: 594-612.

Stiglitz, Joseph E., Nicholas Stern, Maosheng Duan, Ottmar Edenhofer, Gaël Giraud, Geoffrey M. Heal, Emilio Lèbre La Rovere, Adele Morris, Elisabeth Moyer, and Mari Pangestu. 2017. "Report of the High-Level Commission on Carbon Prices."

Summers, Larry. 2019. "The Left's Embrace of Modern Monetary Theory Is a Recipe for Disaster." Washington Post, April 3, 2019.

Volz, Ulrich. 2017. "On the Role of Central Banks in Enhancing Green Finance." UNEP Inquiry. https://unepinquiry.org/publication/on-the-role-of-central-banks-in-enhancing-greenfinance/.

World Bank. 2021. "Carbon Pricing Dashboard.” Carbon Pricing Dashboard. 2021. https://carbonpricingdashboard.worldbank.org/.

Wray, L. Randall, and Yeva Nersisyan. 2019. "How to Pay for the Green New Deal." Working Paper No. 931. Working Paper Series. Annandale-on-Hudson: Levy Economics Institute. 